\title{
Decorin reduces white matter pathology in experimental hydrocephalus: a diffusion tensor imaging and immunohistochemical study
}

\author{
James Patterson McAllister ${ }^{1,3^{*}}$, Anuriti Aojula ${ }^{2}$, Hannah Botfield², Osama Abdullah ${ }^{3}$, Ana Maria Gonzalez ${ }^{2}$, \\ Dustin Ragan', Ann Logan², Alexandra Sinclair ${ }^{2}$
}

From Hydrocephalus 2015

Banff, Canada. 18-21 September 2015

\section{Introduction}

We have shown previously that Decorin, by antagonizing TGF- $\beta$-mediated subarachnoid fibrosis, prevents ventriculomegaly in experimental juvenile hydrocephalus. To focus on white matter alterations, we sought to correlate cytopathological changes induced by hydrocephalus with diffusion tensor imaging (DTI) parameters and determine if Decorin could prevent these changes.

\section{Methods}

Communicating hydrocephalus was induced in 3-week-old rats with basal cistern injections of kaolin; age-matched controls were intact $(n=4)$ and kaolin-no treatment $(n=4)$ animals. Immediately following kaolin injections, animals received a 14-day continuous intraventricular infusion of phosphate-buffered saline $(n=6)$ or human recombinant Decorin $(n=5)$ via osmotic minipumps. At 14 days postkaolin, all rats underwent MRI/DTI scanning followed immediately by sacrifice and brain fixation. DTI voxelbased analysis was performed on 4 serial rostral-to-caudal slices to quantify mean fractional anisotropy (FA), diffusivity (MD), axial diffusivity (AD) and radial diffusivity (RD) of the corpus callosum (CC) and periventricular white matter (PVWM). Immunohistochemistry and stereology were employed to quantify astrogliosis (GFAP) and aquaporin-4 (AQP4) levels in the CC and PVWM at caudal levels.

\section{Results}

Compared to intact animals (rostral $1.3 \pm 0.1$ and caudal 0.9 \pm 0.1 ventricular volume), the caudal lateral ventricles were significantly larger in kaolin-only $(16.2 \pm 2.8, \mathrm{p}=0.005)$ and

\footnotetext{
* Correspondence: pat.mcallister@wustl.edu

${ }^{1}$ Neurosurgery, Washington University School of Medicine, USA

Full list of author information is available at the end of the article
}

kaolin-PBS (21.0 $\pm 5.4, \mathrm{p}<0.001)$ animals than rostral portions $(8.0 \pm 1.7$ and $10.1 \pm 3.8$, respectively). Following this gradient, untreated hydrocephalic rats exhibited significantly $(\mathrm{p}<0.01)$ decreased FA and increased RD in the caudal-most CC and increased MD and AD in the caudal PVWM compared to intact controls. Decorin significantly $(\mathrm{p}<0.05)$ reversed the RD and MD changes in the caudal CC and PVWM MD $(p<0.05)$. Such DTI reversals were not discovered in the rostral CC and PVWM. A significant increase in GFAP immunostaining resulted in a positive correlation $(\mathrm{p}<0.05)$ between CC GFAP levels and the caudal-most CC RD. In the caudal PVWM, MD and AQP4 levels and AD and GFAP presence were positively correlated $(\mathrm{p}<0.01)$.

\section{Conclusions}

These results indicate that regional differences exist in ventricular and DTI parameters, and that Decorin has the therapeutic potential to decrease microstructural damage in juvenile hydrocephalus.

\footnotetext{
Authors' details

${ }^{1}$ Neurosurgery, Washington University School of Medicine, USA

${ }^{2}$ Neurotrauma and Neurodegeneration, School of Clinical and Experimental Medicine, University of Birmingham, UK. ${ }^{3}$ Bioengineering, University of Utah, USA.

Published: 18 September 2015

\section{References}

1. Botfield Hannah, Gonzalez Maria Ana, Abdullah Osama, Skjolding Anders, Berry Martin, McAllister PJames II, Logan Ann: Decorin prevents the development of juvenile communicating hydrocephalus. Brain 2013 136:2842-2858.

2. McAllister PJames II, Michael AWilliams, Walker Marion, Kestle RWJohn, Relkin RNorman, Anderson MAmy, Gross Paul, Browd RSamuel: An update on research priorities in hydrocephalus: overview of the third National
} 
Institutes of Health-sponsored symposium "Opportunities for

Hydrocephalus Research: Pathways to Better Outcomes". J Neurosurg

2015.

3. Morales DM, Holubkov R, Inder T E, Ahn HC, Mercer D, Rao R, McAllister JP II, Holtzman DM, Limbrick DD Jr: Cerebrospinal fluid levels of amyloid precursor protein are associated with ventricular size in post-hemorrhagic hydrocephalus of prematurity. PLoS One 2015, 10(3):e0115045.

doi:10.1186/2045-8118-12-S1-059

Cite this article as: McAllister et al:: Decorin reduces white matter pathology in experimental hydrocephalus: a diffusion tensor imaging and immunohistochemical study. Fluids and Barriers of the CNS 201512

(Suppl 1):059.

Submit your next manuscript to BioMed Central and take full advantage of:

- Convenient online submission

- Thorough peer review

- No space constraints or color figure charges

- Immediate publication on acceptance

- Inclusion in PubMed, CAS, Scopus and Google Scholar

- Research which is freely available for redistribution

Submit your manuscript at www.biomedcentral.com/submit
C Biomed Central 